\title{
Urea production and turnover following the addition of AMP, CMP, RNA and a protein mixture to a marine sediment
}

\author{
Mette S. Therkildsen ${ }^{1}$, Gary M. King ${ }^{2}$, Bente Aa. Lomstein ${ }^{1, *}$ \\ 'Department of Microbial Ecology, Institute of Biological Sciences, University of Aarhus, Denmark \\ ${ }^{2}$ Darling Marine Center, University of Maine, Walpole, Maine 04573, USA
}

\begin{abstract}
The potential of adenosine 5'-monophosphate (AMP), cytidine 5'-monophosphate (CMP), $16 \mathrm{~S}$ ribosomal RNA, and a protein (bovine serum albumin) to serve as substrates for bacterial urea production was evaluated in a defaunated, anoxic marine sediment. AMP, CMP and RNA stimulated urea production and urea turnover, but CMP to a lesser degree than AMP and RNA. The increase in urea production and turnover rates took place immediately after AMP, CMP, and RNA were added to the sediment. The rapid response in urea production and turnover rates suggests that the necessary uptake mechanisms and enzymes to utilize the substrates were present constitutively. Addition of the protein mixture did not result in any measurable changes in the urea pool size, urea turnover rate, or urea production rate during the $165 \mathrm{~h}$ of incubation. However, an increased and continuous net $\mathrm{NH}_{4}{ }^{+}$production in the protein-amended sediment relative to the control sediment indicated that the added protein mixture was accessible for bacterial degradation. The results showed that purines and pyrimidines were substrates for the bacterial urea production in the marine sediment, whereas protein was not important for urea production.
\end{abstract}

KEY WORDS: Urea production · Nucleic acid Protein - Bacteria Marine Sediment

\section{INTRODUCTION}

Urea can account for a substantial amount of the nitrogen leaving the sediment (Boucher \& BoucherRodoni 1988, Lomstein et al. 1989, Lomstein \& Blackburn 1992) and can thus be an important nitrogen source for primary production in marine environments (Remsen 1971, McCarthy et al. 1977, Sörensson \& Sahlsten 1987, Price \& Harrison 1988, Cochlan \& Harrison 1991). However, the urea efflux from the sediment only accounts for a minor fraction of total benthic urea production (Lomstein et al. 1989, Therkildsen \& Lomstein 1994), of which most is produced by bacteria (Pedersen et al. 1993). Sediment urea production is stimulated by the input of readily degradable organic material, as for instance newly sedimented phyto-

-Addressee for correspondence.

E-mail: bente@pop.bio.aau.dk plankton cells, and by benthic macrofaunal activity (Lomstein et al. 1989). Bacterial urea synthesis can occur via several pathways: (1) the ornithine cycle (Meijer et al. 1990); (2) arginine degradation (Cunin et al. 1986): (3) degradation of purines and pyrimidines (Vogels \& Van der Drift 1976, Busse et al. 1984, Gottschalk 1986); and (4) as a by-product in the synthesis of putrescine (Morris \& Koffron 1967). The relative importance of these different pathways in marine sediment is unknown.

Novitsky \& Karl (1985) found relatively high concentrations of extracellular DNA and RNA in a marine sediment. The concentrations of DNA and RNA were 224 and $124 \mu \mathrm{g} \mathrm{g}^{-1}$ (dry weight), respectively, in the $1.5-3.0 \mathrm{~cm}$ horizon in a sandy sediment, and the authors suggested that $75 \%$ of these pools were of extracellular origin. Further, a study by Novitsky (1986) showed that these nucleic acid pools were dynamic and that they were turned over rapidly. This 
implies that there is a potential for urea production from these substrates in marine sediments. It has been shown that both amino acids (Burdige 1991) and urea (Lomstein et al. 1989) are important in the production of $\mathrm{NH}_{4}{ }^{+}$in marine sediments, and it has been suggested that urea may be an intermediate in the degradation of amino acids to $\mathrm{NH}_{4}^{+}$(Hansen et al. 1993, Pedersen et al. 1993).

A substrate addition experiment was conducted with defaunated, muddy, anoxic marine sediment to evaluate the potential of AMP (adenosine 5'-monophosphate), CMP (cytidine 5'-monophosphate), RNA (16S ribosomal RNA), and protein (bovine serum albumin) as precursors for bacterial urea production. The concentration, turnover, and production of urea and the concentration of $\mathrm{NH}_{4}{ }^{+}$were followed in the amended and unamended sediment during a $165 \mathrm{~h}$ incubation.

\section{MATERIALS AND METHODS}

Sampling and sample treatment. Sediment from 1 to $8 \mathrm{~cm}$ depth was collected in Clarks Cove, Walpole, Maine, USA. After returning to the laboratory the sediment was passed through a $1 \mathrm{~mm}$ sieve to remove macrofauna. The sediment was stored in the dark under anoxic conditions at $15^{\circ} \mathrm{C}$ for $10 \mathrm{~d}$ to eliminate macro- and meiofauna. Absence of animals was confirmed microscopically at the beginning of the experiment.

The sediment was thoroughly mixed and $1053 \mathrm{~g}$ of undiluted sediment was transferred to each of five 11 glass bottles. The bottles were flushed with $\mathrm{N}_{2}$ to remove $\mathrm{O}_{2}$, and stored overnight. Anoxic incubation conditions prevented nitrification, and thus faciliated mass balance calculations for nitrogen. The bottles were placed on a bottle roller to ensure continuous mixing of the sediment. Sampling from the bottles was performed with $\mathrm{N}_{2}$ flushing to avoid oxygenation of the sediment. All experiments were carried out at $24^{\circ} \mathrm{C}$ and in the dark

Sediment characteristics. Sediment density, water content, and concentration of total organic carbon and nitrogen were determined at the beginning and the end of the experiment. Water conten.t was determined as the weight loss from sediment dried at $105^{\circ} \mathrm{C}$ for $24 \mathrm{~h}$. Total organic carbon and nitrogen were determined on $\mathrm{H}_{2} \mathrm{SO}_{3}$ treated, dried and homogenized sediment in a Carlo Erba NA $1500 \mathrm{C} / \mathrm{N}$ analyzer

Addition of substrate. All substrates were obtained from Sigma Chemical Co., and used at the following final concentrations: AMP, $0.95 \mathrm{mM}(4.75 \mathrm{mM} \mathrm{N})_{i}$ CMP, $0.95 \mathrm{mM} \quad(2.85 \mathrm{mM} \quad \mathrm{N}) ;$ RNA, $\sim 1.65 \mathrm{mM}$ nucleotide $(-5.9 \mathrm{mMN})$; protein, $-7.3 \mathrm{mM} \mathrm{N}$. Samples for urea and $\mathrm{NH}_{4}{ }^{+}$concentrations and urea turnover rates were obtained at $-9 \mathrm{~h}$ intervals during the first $65 \mathrm{~h}$ of incubation. During the remaining incubation. period ( 65 to $165 \mathrm{~h}$ ) samples were obtained at greater intervals, and only urea and $\mathrm{NH}_{4}{ }^{+}$concentrations were measured.

Urea and $\mathrm{NH}_{4}{ }^{+}$concentrations. Concentrations of urea and $\mathrm{NH}_{4}{ }^{+}$were measured after $\mathrm{KCl}$ extraction: $1 \mathrm{ml}$ of $0.8 \mathrm{M} \mathrm{KCl}$ was added to $\sim 7.6 \mathrm{~g}$ of sediment. The extraction was terminated after 10 min by centrifugation, and the supernatant was frozen for later analysis. Urea concentrations were measured using the diacetylmonoxime method (Price \& Harrison 1987), and $\mathrm{NH}_{4}{ }^{+}$concentrations by the salicylate-hypochlorite method (Bower \& Holm-Hansen 1980). The KCl treatment of the sediment had no effect on the measured urea pool size

Urea turnover. Urea turnover rates were measured using a short-term radioassay as described by Lund \& Blackburn (1989). At each sampling point, 12 samples of $7.6 \mathrm{~g}$ were collected from each treatment, transferred to tubes, and flushed with $\mathrm{N}_{2}$. Half of the samples were used to follow the change in urea concentration during incubation; the remaining samples were injected with ${ }^{14} \mathrm{C}$-urea. The ${ }^{14} \mathrm{C}$-urea incubation was modified slightly from Lund \& Blackburn (1989): (1) the incubation was performed as a 3-point time course $(\sim 0,1,2 \mathrm{~h}),(2)$ the activity of the injected $10 \mu \mathrm{l}$

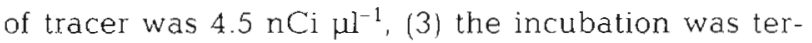
minated by adding $1 \mathrm{ml} 6 \% \mathrm{NaOH}_{\text {, }}$ (4) the scintillation fluid was Scintiverse BD (Fisher Scientific) that was $\mathrm{pH}$ adjusted in order to avoid. $\mathrm{CO}_{2}$ evaporation from samples $(1 \mathrm{ml}$ of $0.1 \mathrm{M} \mathrm{NaOH}$ was mixed with $10 \mathrm{ml}$ of Scintiverse BD). Urea turnover rates were calculated by the nonsteady-state model I and the steady-state model II, respectively, described in Lund \& Blackburn (1989). It was not possible to calculate the standard deviation of the urea turnover rates when they were calculated by model I, as this model involves a linear regression of dependent variables. The urea production rate was calculated as the sum of the urea turnover rate and the change in the urea concentration.

\section{RESULTS}

\section{Sediment characteristics}

The water content of the sediment was $0.57 \mathrm{ml} \mathrm{g}^{-1}$ and the density was $1.36 \mathrm{~g} \mathrm{~cm}^{-3}$. Both parameters remained constant throughout the experiment. Total organic carbon and nitrogen in the sediment were $698 \pm 26 \mu \mathrm{mol} \mathrm{C} \mathrm{cm} \mathrm{cm}^{-3}$ and $84 \pm 4 \mu \mathrm{mol} \mathrm{N} \mathrm{cm}^{-3}$, respectively, at the beginning of the incubations. 


\section{Urea concentration}

Urea concentrations varied between 1.5 and 3.7 $\mu \mathrm{mol} \mathrm{N} \mathrm{l}$ ' (average $2.5 \pm 0.7 \mu \mathrm{mol} \mathrm{N}{ }^{-1}$ ) in the control sediment, and between 1.8 and $3.7 \mu \mathrm{mol} \mathrm{N}^{-1}$ (average $2.7 \pm 0.5 \mu \mathrm{mol} \mathrm{N} \mathrm{l}^{-1}$ ) in the protein-amended sediment (Fig. 1). During the first $24 \mathrm{~h}$ of incubation, urea increased in the AMP- and RNA-amended sediment to 23.9 and $33.4 \mu \mathrm{mol} \mathrm{N}{ }^{-1}$, respectively, whereafter the urea concentrations decreased in the 2 treatments (Fig. 1). The AMP-amended sediment reached the control level after $\sim 77 \mathrm{~h}$ of incubation, whereas the urea concentration in the RNA-amended sediment did not reach the control level before the end of the experiment $(\sim 165 \mathrm{~h})$. There was a minor initial increase (to $6.6 \mu \mathrm{mol}$ urea- $\mathrm{N}^{-1}$ ) in the CMP-treated sediment, but the urea concentration decreased to control values after $\sim 45 \mathrm{~h}$ of incubation.

\section{Urea turnover rates and kinetics}

The urea turnover rates varied between 1.5 and $3.3 \mu \mathrm{mol}$ urea- $\mathrm{N}^{-1} \mathrm{~h}^{-1}$ (average $2.4 \pm 0.7 \mu$ mol urea- $\mathrm{N}$ $\mathrm{l}^{-1} \mathrm{~h}^{-1}$ ) in the control, and between 1.8 and $3.1 \mu \mathrm{mol}$ urea- $\mathrm{N} \mathrm{l}^{-1} \mathrm{~h}^{-1}$ (average $2.6 \pm 0.4 \mu \mathrm{mol}$ urea- $\mathrm{N}^{-1} \mathrm{~h}^{-1}$ ) in the protein-treated sediment (Fig. 2). Urea turnover rates in the AMP, CMP, and RNA treatments reached a maximum after $\sim 23 \mathrm{~h}$ of $16.0,6.5$, and $24.2 \mu \mathrm{mol}$ urea$\mathrm{N}^{-1} \mathrm{~h}^{-1}$, respectively (Fig. 2). After $\sim 65 \mathrm{~h}$ incubation the urea turnover rates had declined to 6.0, 0.9, and $4.6 \mu \mathrm{mol}$ urea $-\mathrm{N}^{-1} \mathrm{~h}^{-1}$, respectively.

\section{Urea production}

Urea production rates in the AMP, CMP, and RNA treatments reached a maximum after $\sim 23 \mathrm{~h}$ of $16.0,6.5$, and $24.2 \mu \mathrm{mol}$ urea- $\mathrm{N}^{-1} \mathrm{~h}^{-1}$, respectively (Fig. 3). The integrated ( $\sum 0$ to $65 \mathrm{~h}$ ) urea productions were 159 and $177 \mu \mathrm{mol}$ urea- $\mathrm{N}^{-1}$, respectively, in the control and protein-amended sediments, and 681, 238, and 852 $\mu$ mol urea- $\mathrm{N}^{-1}$ in the AMP-, CMP-, and RNA-treated sediments, respectively (Table 1 ).

\section{$\mathrm{NH}_{4}{ }^{+}$concentration and net $\mathrm{NH}_{4}{ }^{+}$production}

The increases of the $\mathrm{NH}_{4}{ }^{+}$concentration in the control and the protein-amended sediment were linear throughout the incubation (Fig. 4). However, the net $\mathrm{NH}_{4}{ }^{+}$production rate was greater in the proteinamended sediment than in the control sediment $(20.3$ and $5.8 \mu \mathrm{mol} \mathrm{l}^{-1} \mathrm{~h}^{-1}$, respectively). There was a dramatic increase in the $\mathrm{NH}_{4}{ }^{+}$concentration in the AMP-

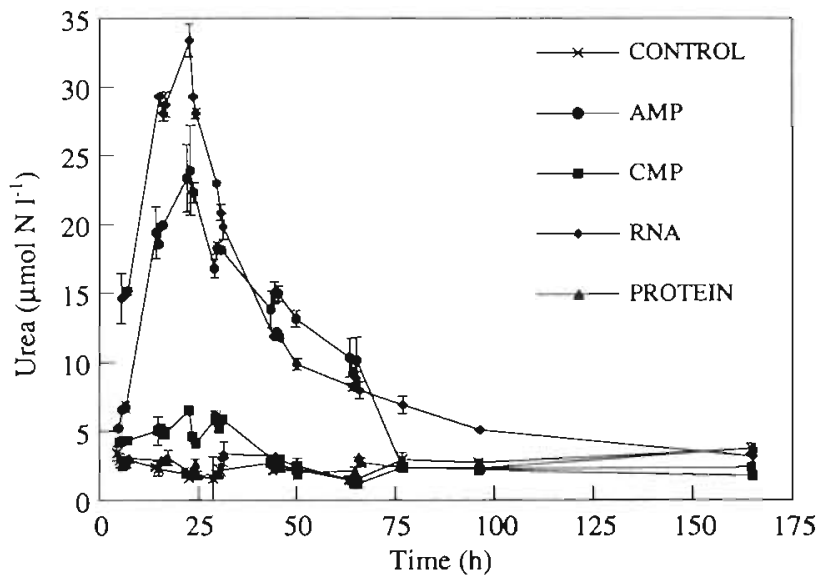

Fig. 1. Changes in the urea concentration in sediment incubations after substrate addition ( \pm standard error)

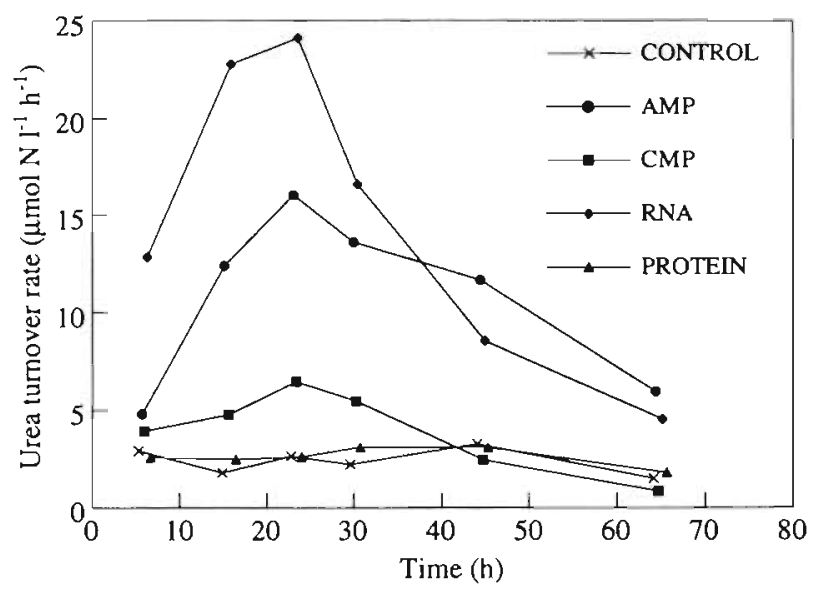

Fig. 2. Changes in the urea turnover rate in sediment incubations after substrate addition.

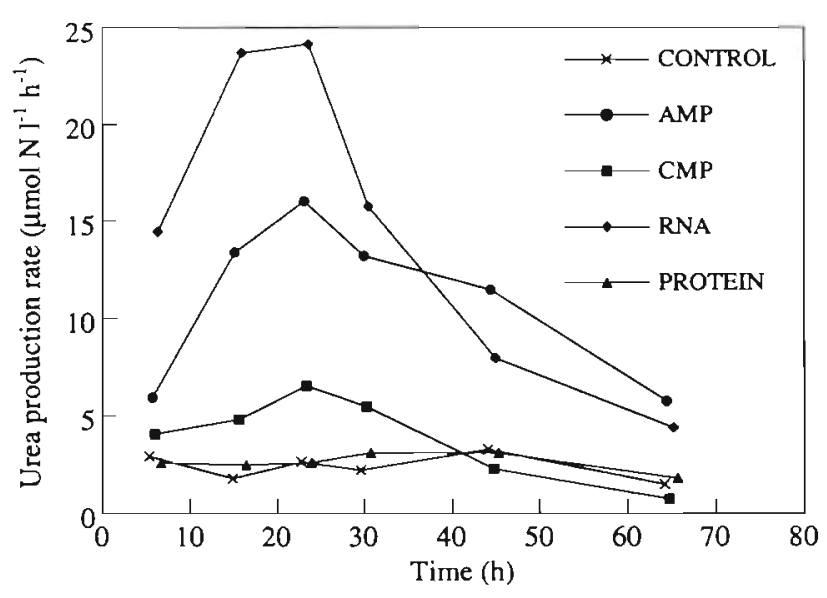

Fig. 3. Changes in the urea production rate in sediment incubations after substrate addition 
Table 1. Integrated rate of urea production, urea turnover, and net $\mathrm{NH}_{4}{ }^{+}$production in sediment incubations

\begin{tabular}{|c|c|c|c|c|}
\hline \multirow{3}{*}{$\begin{array}{l}\text { Subtrate } \\
\text { Control }\end{array}$} & \multirow{2}{*}{\multicolumn{2}{|c|}{$\begin{array}{l}\text { Urea production Urea turnover } \\
\sum 0 \text { to } 65 \mathrm{~h} \quad \sum 0 \text { to } 65 \mathrm{~h} \\
\left(\mu \mathrm{mol} \text { urea }-\mathrm{N}^{-1}\right)\end{array}$}} & \multicolumn{2}{|c|}{ Net $\mathrm{NH}_{4}^{+}$production } \\
\hline & & & \multicolumn{2}{|c|}{$\sum 0$ to $\left.65 \mathrm{~h} \sum_{(\mu \mathrm{mol} \mathrm{I}} \sum^{-1}\right)$} \\
\hline & 159 & 162 & 411 & 894 \\
\hline AMP & 681 & 684 & 2645 & 3022 \\
\hline CMP & 238 & 236 & 1575 & 2261 \\
\hline RNA & 852 & 862 & 3531 & 4117 \\
\hline Protein & 177 & 175 & 1266 & 3016 \\
\hline
\end{tabular}

and RNA-treated sediment during the first $30 \mathrm{~h}$ of incubation (Fig. 4). In the CMP-treated sediment, net $\mathrm{NH}_{4}^{+}$production was greater in the CMP sediment than in the control during the first $50 \mathrm{~h}$ of incubation. During the remaining part of the experiment the net $\mathrm{NH}_{4}^{+}$production rates in the AMP-, CMP-, and RNA-treated sediments were comparable to that of the control sediment (Fig. 4)

The integrated $\left(\sum 0\right.$ to $65 \mathrm{~h}$ and $\sum 0$ to $165 \mathrm{~h}$ ) net $\mathrm{NH}_{4}{ }^{+}$productions were

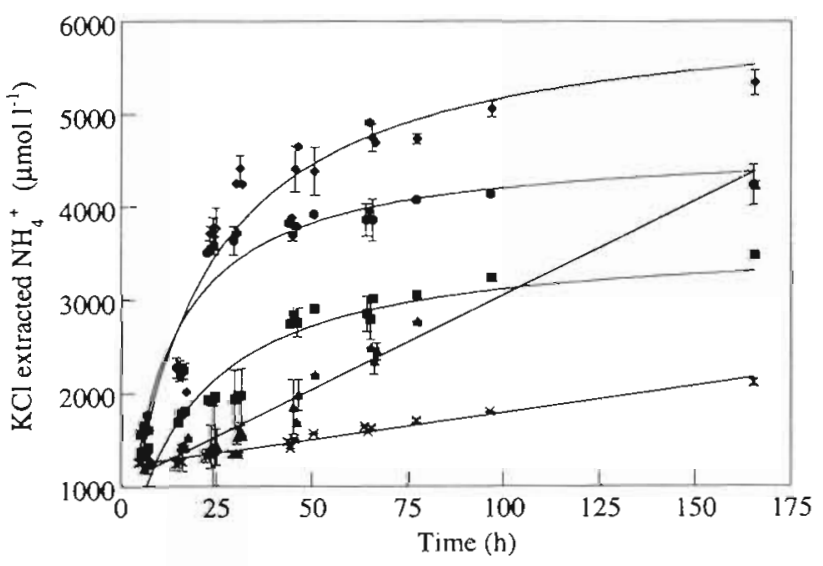

Fig. 4. Changes in the concentration of $\mathrm{KCl}$-extractable $\mathrm{NH}_{4}{ }^{+}$in sediment incubations after substrate addition ( \pm standard error). The following curve fits were made to make the tendencies more obvious: $(x)$ control, $y=1218+5.8 x(\mathrm{r}=0.98)$; ( $)$ AMP, $y$ $=4671 \mathrm{x} /(x+11)(\mathrm{r}=0.96)_{i}$ (口) CMP, $y=3649 x /(x+17)$ $(\mathrm{r}=0.93)_{i}(\bullet)$ RNA, $y=6155 x /(x+19)(\mathrm{r}=0.95)_{i}(\Delta)$ protein, $y=$ $1037+20 \times(r=0.99)$

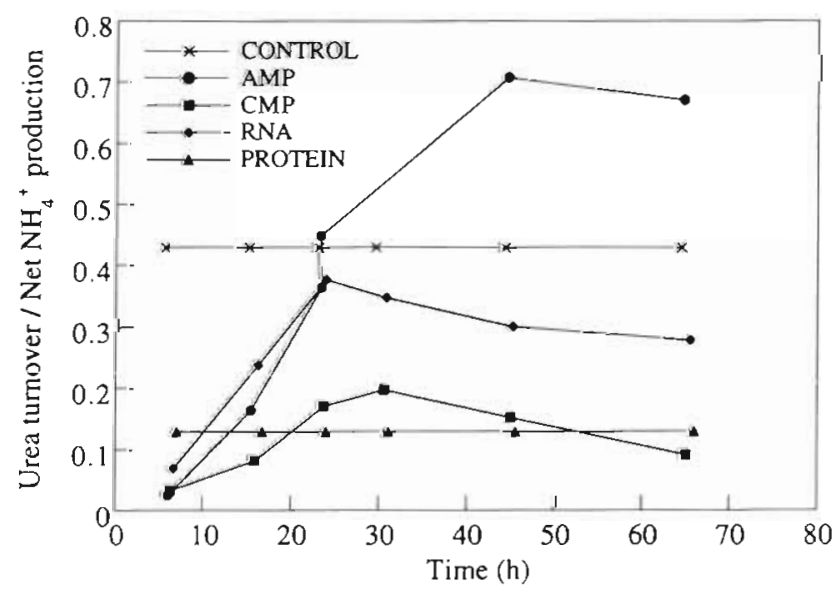

Fig. 5. Changes in the ratio between the urea turnover rate and the net $\mathrm{NH}_{4}{ }^{+}$production rate during the furst $65 \mathrm{~h}$ in sediment uncubations. The ratio in the control sediment was calculated as the average urea turnover rate $\left(2.4 \pm 0.7 \mu \mathrm{mol} \mathrm{N} \mathrm{l}^{-1}\right)$ divided by the constant net $\mathrm{NH}_{4}$ ' production rate calculated as the change in the $\mathrm{NH}_{4}{ }^{+}$pool size during the time span of interest. The initial $\mathrm{NH}_{4}{ }^{+}$pool size was determined to have been $1218 \mu \mathrm{M}$ in all sediments (determined from the control curve fit in Fig. 4). The integrated net $\mathrm{NH}_{4}{ }^{+}$production ( $\sum 0$ to $165 \mathrm{~h}$ ) in the different treatments was $894,3022,2261,4117$, and $3016 \mu \mathrm{mol} \mathrm{l}^{-1}$ in the control, AMP-, CMP-, RNA-, and protein-amended sediments, respectively (Table 1).

The ratio between the urea turnover rate and the net $\mathrm{NH}_{4}{ }^{+}$production rate increased from 0.03 (5.7 h) to a maximum of $0.71(44.5 \mathrm{~h})$ in AMP-treated sediment (Fig. 5). In the CMP-and RNA-treated sediments urea turnover/net $\mathrm{NH}_{4}{ }^{+}$production increased from 0.03 $(6.0 \mathrm{~h})$ to $0.20(30.3 \mathrm{~h})$ and from $0.07(6.3 \mathrm{~h})$ to 0.38 $(23.7 \mathrm{~h})$, respectively (Fig 5$)$. The ratio between the urea turnover rate and the net $\mathrm{NH}_{4}{ }^{+}$production rate remained constant at 0.43 and 0.13 in the control and protein-amended sediments, respectively.

\section{DISCUSSION}

\section{Urea production from AMP, CMP and RNA}

The rapid increase in urea production and turnover after the addition of AMP, CMP, and RNA (Figs. 2 \& 3) indicates that mineralization of these substrates is coupled to urea dynamics in vitro, and that extracellular nucleic and polynucleic acids may serve as urea precursors in situ. Urea production and turnover rates in the AMP, CMP and RNA treatments were within the range reported for a shallow estuary in July, where the turnover rate of urea was $>350 \mathrm{nmol} \mathrm{cm}^{-3} \mathrm{~d}^{-\mathrm{i}}$ within the upper $1 \mathrm{~cm}$ of the sediment (Therkildsen \& Lomstein 1994) Therkildsen \& Lomstein (1994) concluded that urea production was stimulated by the availability of high quality organic material (low $\mathrm{C} / \mathrm{N}$ ) and temperature. The most likely source of organic matter input to the sediment in the Therkildsen \& Lomstein (1994) study was benthic and pelagic microalgae cells. Based on the present study it is probable that it was degradation of microalgal RNA (+IDNA) that stimulated urea 
production in the Therkildsen \& Lomstein (1994) study The amount of substrate RNA added in the present experiment was equivalent to a potential increase in sediment RNA+DNA due to a phytoplankton sedimentation event. Based on the content of RNA+DNA in a Euglena sp. cell (Smillie \& Krotkov 1960), an algal carbon content of $10 \%$ of algal dry weight, an annual primary production of $300 \mathrm{~g} \mathrm{C} \mathrm{m}^{-2}$ (typical for Danish coastal waters) and an assumed $2 \mathrm{~mm}$ thick sediment surface zone that is affected by algal sedimentation, we calculated that the addition of RNA to the sediment in the present experiment was equivalent to an algal input of $2.9 \mathrm{~g} \mathrm{C} \mathrm{m}^{-2}(\sim 1 \%$ of the annual primary production) However, the stimulation of urea production and turnover by the addition of AMP and CMP may not have been representative of natural conditions, as the input of AMP and CMP to the sediment from microalgal cells can be expected to be much lower than the addition made in the present experiment. The stimulation of urea turnover by the addition of these substrates should therefore only be considered as indicative of anaerobic bacterial urea production from these substrates.

The turnover of bacterial intracellular nucleic acids, especially RNA, may also have contributed to urea production in addition to the turnover of extracellular nucleic acids taken up by the bacterial cells. Cellular RNA is degraded continuously during exponential growth and this may lead to excretion of urea or $\mathrm{NH}_{4}{ }^{+}$. Culture experiments with the marine bacterium Thiosphaera pantotropha grown on a minimal medium showed that urea was excreted at a rate proportional to cell density during exponential growth, and that urea production continued after the bacteria entered the stationary phase (Pedersen et al. 1993). Similar results have been obtained in other culture studies (Therkildsen et al. unpubl.), supporting the idea that degradation of intracellular nucleic acids may contribute to urea production.

\section{Degradation pathways of AMP, CMP, and RNA}

Bacteria degrade purines (e.g. AMP) by 2 pathways under anoxic conditions, one of which gives rise to $\mathrm{NH}_{4}{ }^{+}$(Gottschalk 1986), the other to $\mathrm{NH}_{4}{ }^{+}$and urea (Busse et al. 1984, Kaspari \& Busse 1986). Both pathways appeared functional in our experiment, as more $\mathrm{NH}_{4}{ }^{+}$was produced within the first $65 \mathrm{~h}$ of incubation than could be accounted for by urea production and turnover. Urea turnover $\left(\sum 0\right.$ to $\left.65 \mathrm{~h}\right)$ in the AMPtreated sediment [urea turnover (AMP) - urea turnover (control)] only accounted for $23 \%$ of the corresponding net $\mathrm{NH}_{4}{ }^{+}$production. The ratio between urea turnover and $\mathrm{NH}_{4}^{+}$production might, however, have been even lower if gross $\mathrm{NH}_{4}{ }^{+}$production had been considered instead of net $\mathrm{NH}_{4}{ }^{+}$production. One has to keep in mind that net $\mathrm{NH}_{4}^{+}$production did not include the fraction of $\mathrm{NH}_{4}{ }^{+}$production that was incorporated into bacterial biomass. Blackburn \& Henriksen (1983), in a study of nitrogen cycling in different types of sediments from Danish waters, found that $\mathrm{NH}_{4}{ }^{+}$incorporation into bacterial biomass varied between 22 and $83 \%$ of gross $\mathrm{NH}_{4}{ }^{+}$production within the upper $2 \mathrm{~cm}$ of the sediment. Approximately $11 \%$ of the added AMP-N was mineralized to $\mathrm{NH}_{4}{ }^{+}$with urea as an intermediate during the first $65 \mathrm{~h}$ of incubation. However, this fraction was probably higher at the end of the experiment (165 h), since urea production and turnover were still elevated in the AMP-treated sediment compared to the control at the final point of urea turnover measurements $(65 \mathrm{~h})$. Previous investigations have shown that up to $80 \%$ of added AMP-N can be degraded through urea (Busse et al. 1984, Kaspari \& Busse 1986).

Anaerobic pyrimidine degradation produces urea and $\mathrm{NH}_{4}{ }^{+}$via an oxidative pathway, while only $\mathrm{NH}_{4}{ }^{+}$is produced by a reductive pathway (Vogels \& Van der Drift 1976, Gottschalk 1986). The reductive pathway probably dominated in the present study, as urea turnover in the CMP-treated sediment ( $\sum 0$ to $65 \mathrm{~h}$ ) only accounted for $6 \%$ of the integrated net $\mathrm{NH}_{4}^{+}$production. Further, only $3 \%$ of the added CMP-N was degraded via urea after $65 \mathrm{~h}$ incubation compared to at least $41 \%$ via $\mathrm{NH}_{4}{ }^{+}$. A theoretical maximum of $67 \%$ of the added CMP-N can potentially be degraded through urea if CMP is degraded through the oxidative pathway (Vogels \& Van der Drift 1976).

Approximately $12 \%$ of the added RNA-N was degraded via urea in the RNA-treated sediment during the first $65 \mathrm{~h}$ of incubation. Further, the excess urea turnover ( $\sum 0$ to $65 \mathrm{~h}$ ) could explain $22 \%$ of the corresponding net $\mathrm{NH}_{4}{ }^{+}$production.

The ratio between the urea turnover rate and the net $\mathrm{NH}_{4}{ }^{+}$production rate was much lower in the AMP-, CMP-, and RNA-treated sediment during the first $65 \mathrm{~h}$ of the experiment $(\sim 0.04)$ than in the control sediment (0.4; Fig. 5). This was due to very high net $\mathrm{NH}_{4}^{+}$production rates. These high net $\mathrm{NH}_{4}^{+}$production rates were probably a result of deamination, which is the initial step in the degradation of both adenine and cytosine (Vogels \& Van der Drift 1976, Busse et al. 1984, Gottschalk 1986, Kaspari \& Busse 1986). Urea turnover gradually increased relative to net $\mathrm{NH}_{4}{ }^{+}$production as degradation progressed. In the CMP-treated sediment, however, the urea turnover remained low relative to the net $\mathrm{NH}_{4}{ }^{+}$production $(0.2)$. This is in agreement with the predominance of the reductive degradation pathway for CMP. In contrast, the urea turnover rate could account for a greater fraction of the net $\mathrm{NH}_{4}{ }^{+}$ production rate in the AMP-treated sediment than in the control after $-30 \mathrm{~h}$. 
Net $\mathrm{NH}_{4}{ }^{+}$production rates and urea concentrations in the AMP-, CMP-, and RNA-treated sediments equaled those in the control at the end of the experiment (165 h). Thus, the urea production rates at the end of the experiment were probably similar to the rate in the control. Although mineralization of the exogenous AMP, CMP, and RNA apparently had ceased, the integrated excess net $\mathrm{NH}_{4}{ }^{+}$production ( 20 to $165 \mathrm{~h}$ ) in the AMP-, CMP-, and RNA-treated sediments only accounted for 45,48 and $-55 \%$, respectively, of the added $N$. This is comparable to results obtained by Novitsky (1986), who found that 62 to $72 \%$ of added RNA was degraded in a marine sediment within $14 \mathrm{~d}$ and that most of the degradation took place within the first 3 to $7 \mathrm{~d}$.

There are, however, several explanations for the less than $100 \%$ recovery of added substrates in the integrated net $\mathrm{NH}_{4}{ }^{+}$production: (1) as already mentioned part of the added $\mathrm{N}$ may have been incorporated into microbial biomass; (2) adsorption of substrates to sediment (e.g. Greaves \& Wilson 1969, Lorenz \& Wackernagel 1987); and (3) degradation to N-compounds other than urea and $\mathrm{NH}_{4}{ }^{+}$.

\section{Protein mixture (bovine serum albumin)}

The addition of a protein mixture did not result in any measurable changes in urea concentration, urea turnover or urea production (Figs. 1, $2 \& 3$ ). There was, however, an immediate increase in the concentration of $\mathrm{KCl}$-extractable $\mathrm{NH}_{4}{ }^{+}$Further, the net $\mathrm{NH}_{4}{ }^{+}$production rate in the protein-treated sediment was about 3.5 times higher than in the control. The integrated net $\mathrm{NH}_{4}{ }^{+}$production during the entire experiment 10 to $165 \mathrm{~h}$ ) was equal to $29 \%$ of added protein- $\mathrm{N}$ and the $\mathrm{NH}_{4}{ }^{+}$production rate was still elevated compared to the control, when the experiment was terminated. The increased and continuous $\mathrm{NH}_{4}{ }^{+}$production during the entire time span of incubation indicates that the added protein was readily available for bacterial degradation. Further, the protein addition $(7.3 \mathrm{mM} \mathrm{N}=5.7 \mu \mathrm{mol}-\mathrm{N}$ $\mathrm{cm}^{-3}$ ) was comparable to the content of total acid hydrolyzable amino acids (THAA-N) in a Danish coastal sediment, where THAA-N varied between 22 and 37 mol- $\mathrm{N} \mathrm{cm}^{-3}$ within the upper $6 \mathrm{~cm}$ (Lomstein et al. unpubl.). Thus, protein addition did not alter the ambient protein pool significantly.

Amino acid $\mathrm{N}$ can be metabolized to urea through the energy-requiring ornithine and citric acid cycles (Meijer et al. 1990). The degradation of the amino acid arginine, which is the precursor for urea in the ornithine cycle, can, however, lead to the formation of urea without an energy cost. Some bacteria have been found to possess a complete ornithine cycle (Gruninger \& Goldman
1988). At present, the relative importance of urea production in marine sediments via the ornithine cycle or arginine degradation is unknown. However, if amino acids and proteins in general are degraded as was the bovine serum albumin in the present experiment, the urea production from protein or amino acids is of minor importance in anoxic marine sediments.

\section{Conclusion}

There was an immediate increase in urea production, urea turnover and net $\mathrm{NH}_{4}{ }^{+}$production due to the addition of RNA, AMP and CMP to an anoxic marine sediment. This indicates that the natural bacteria population possessed the necessary uptake mechanisms and enzymes to utilize the added substrates. The stimulated urea production and turnover rates were comparable to rates obtained in surface sediment from a Danish estuary during summer and it was inferred that stimulation of in situ urea production may be due to RNA input from microalgal cells. Urea production and turnover were not stimulated by the addition of a bovine serum albumin protein mixture to the sediment. This indicates that urea was not an important intermediate in protein turnover.

Acknowledgements. We thank Sylvia Schnell, Peter Roslev and Cem Giray for helpful assistance during the experiments. Financial support was obtained from the Danish Environmental Protection Agency, Hav90, Grant no. 3.25 and from the Centre for Strategic Environmental Research in Marine Areas, Grant no. 4.15.

\section{LITERATURE CITED}

Blackburn TH, Henriksen K (1983) Nitrogen cycling in dufferent types of sediments from Danish waters. Limnol Oceanogr 28:477-493

Boucher G, Boucher-Rodoni R (1988) In situ measurement of respiratory metabolism and nitrogen fluxes at the interface of oyster beds. Mar Ecol Prog Ser 44:229-238

Bower CE, Holm-Hansen $T$ (1980) A salicylate-hypochlonte method for determining ammonia in seawater. Can J Fish Aquat Sci 37:794-798

Burdige DJ (1991) Microblal processes affecting alanine and glutamic acid in anoxic marine sediments. FEMS Microhiol Ecol 85:211-233

Busse W. Kaspari H, Klemme JH (1984) Urea: an intermediate of aerobic and anaerobic punne degradation in Rhodopseudomonas capsulata. FEMS Microbiol Lett 25:33-36

Cochlan WP, Harrison PJ (1991) Uptake of nitrate, ammonium, and urea by nitrogen-starved cultures of Micromonas pusila (Prasinophyceae): transient responses. J Phycol 27:673-679

Cunin R, Glansdorff N, Plerard A, Stalon V (1986) Biosynthesis and metabolism of arginine in bacteria. Microbiol Rev 50:314-352

Gottschalk G (1986) Bacterial metabolism. Springer-Verlag, New York 
Greaves MP, Wilson MJ (1969) The adsorption of nucleic acids by montmorillonite. Soil Biol Biochem 1:317-323

Gruninger SE, Goldman M (1988) Evidence for urea cycle activity in Sporosarcina ureae. Arch Microbiol 150: $394-399$

Hansen LS, Holmer M, Blackburn TH (1993) Mineralization of organic nitrogen and carbon (fish food) added to anoxic sediment microcosms: role of sulphate reduction. Mar Ecol Prog Ser 102:199-204

Kaspari H, Busse W (1986) Oxidative degradation of purnes by the facultative phototrophic bacterium Rhodopseudomonas capsulata. Arch Microbiol 144:67-70

Lomstein BAa, Blackburn TH (1992) Sediment nitrogen cycling in Aarhus Bay, Denmark. Danish Environmental Protection Agency, Copenhagen

Lomstein BAa, Blackburn TH, Henriksen K (1989) Aspects of nitrogen and carbon cycling in the northern Bering Shelf sediment. I. The significance of urea turnover in the mineralization of $\mathrm{NH}_{4}{ }^{*}$. Mar Ecol Prog Ser 57:237-247

Lorenz MG, Wackernagel W (1987) Adsorption of DNA to sand and variable degradation rates of adsorbed DNA. Appl Environ Microbiol 53:2948-2952

Lund BAa, Blackburn TH (1989) Urea turnover in a coastal marine sediment measured by a ${ }^{14} \mathrm{C}$-urea short-term incubatıon. J Microbiol Methods 9:297-308

McCarthy JJ, Taylor WR, Taft JL (1977) Nitrogenous nutrition of the plankton in Chesapeake Bay. 1. Nutrient availability and phytoplankton preferences. Limnol Oceanogr 22: 996-1011

Meijer AJ, Lamers WH, Chamuleau RAFM (1990) Nitrogen

Responsible Subject Editor: T. H. Blackburn, Aarhus, Denmark metabolism and ornithin cycle function. Physiological Rev 70:701-748

Morris DR, Koffron KL. (1967) Urea production and putrescine biosynthesis by Escherichıa coll. J Bacteriol 94:1516-1519

Novitsky JA (1986) Degradation of dead microbial biomass in a marne sediment. Appl Inviron Microbiol 52:504-509

Novitsky JA, Karl DM (1985) Influence of deep ocean sewage outfalls on the microbial dctivuty of the surrounding sediment. Appl Environ Microbiol 50:1464-1473

Pedersen H, Lomstein BAa, Blackburn TH (1993) Evidence for bacterial urea production in marine sediments. FEMS Microbiol Ecol 12:51-59

Price NM. Harrison PJ (1987) Comparison of methods for the analysis of dissolved urea in seawater. Mar Biol 94: $307-317$

Price NM, Harrison PJ (1988) Uptake of urea C and urea N by the coastal marine diatom Thalassiosira pseudonana. Limnol Oceanogr 33:528-537

Remsen CC (1971) The distribution of urea in coastal and oceanic waters. Limnol Oceanogr 16:732-740

Smillie RM, Krotkov G (1960) The estimation of nucleic acids in some algae and higher plants. Can J Bot 38:31-49

Sörensson F, Sahlsten E (1987) Nitrogen dynamics of a cyanobacteria bloom in the Baltic Sea: new versus regenerated production. Mar Ecol Prog Ser 37:277-284

Therkildsen MS, Lomstein BAa (1994) Seasonal variation in sediment urea turnover in a shallow estuary. Mar Ecol Prog Ser 109:77-82

Vogels GD, Van der Drift C (1976) Degradation of purines and pyrimidines by microorganisms. Bacteriol Rev 40:403-468

Manuscript first received: October 24, 1995

Revised version accepted: March 22, 1996 